\title{
Multiple sites acquired lipodystrophy in two siblings: a rare adverse effect of intramuscular triamcinolone
}

\author{
Indar Kumar Sharawat, Jaivinder Yadav, Lesa Dawman ${ }^{\circledR}$
}

Post Graduate Institute of Medical Education and Research, Chandigarh, India

Correspondence to Dr Jaivinder Yadav, jai1984yadav@gmail.com

Accepted 8 June 2019

\section{DESCRIPTION}

A 4-year-old boy presented with focal depression over the bilateral buttocks and right arm for the past one and half months. The depression was non-progressive in nature since it was noticed and was not associated with pain and itching. When history was reviewed, we found that child had multiple papular, itchy lesions over the dorsum of hands, lower abdomen, inguinal and pubic area, and over the upper part of thighs (probably he had scabies) 3 months back. He was shown to a local unqualified clinician (quack) who gave him intramuscular triamcinolone (dose not known) once a day for 4 days over bilateral buttocks and arms. His younger sibling (2-year-old boy) also had similar skin lesions and he too received intramuscular triamcinolone for 4 days and developed focal depression of skin over the right arm and bilateral buttocks. He was born to non-consanguineous parents with unremarkable family history. There was no history suggestive of recurrent boils, acupuncture and chronic inflammatory conditions in both the siblings.

Examination revealed that depressed plaques (slightly hypopigmented to adjoining skin) were observed over bilateral buttocks and lateral aspect of the right arm (figure 1A,B). Similar lesions were also seen in the younger sibling (figure 1C,D). The overlying skin was slightly hypopigmented without any signs of chronic inflammation and vasculitic changes. Antinuclear antibodies and HIV serology were negative in both the siblings. Both the children had normal blood sugar, HbA1c, C- reactive protein, erythrocyte sedimentation rate, and lipid profile. On the basis of temporal association with triamcinolone injection and loss of fat in injection site, a diagnosis of acquired lipodystrophy secondary to intramuscular injection was considered (Naranjo adverse drug reaction probability scale score was 5). Parents refused for skin biopsy and were counselled regarding the nature of the lesions. At 4-month follow-up, the lesions were non progressive in both the children.

The lipodystrophy syndromes are rare heterogeneous acquired or genetically determined disorders characterised by loss of underlying adipose tissue. It affects the entire body (generalised) or can involve certain parts of adipose tissues (partial). The genetic subtypes are congenital generalised lipodystrophy and familial partial lipodystrophy. ${ }^{1}$ Acquired localised lipodystrophy is the most common subtype and occurs with various inflammatory conditions, connective tissue disorders, HIV infection, metabolic syndromes (diabetes mellitus, insulin resistance, dyslipidaemia, and hepatic steatosis), and intramuscular injections. ${ }^{1}$

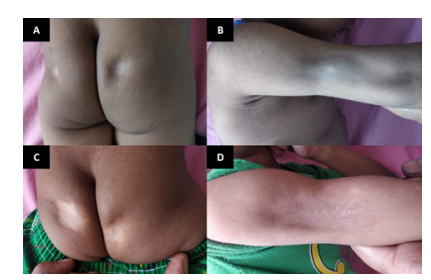

Figure 1 Hypopigmented depressed plaques over bilateral buttocks and lateral aspect of the right arm in the index case $(A, B)$ and younger sibling $(C, D)$.

Intramuscular injections that are associated with localised lipodystrophy are antibiotics (amikacin, gentamycin), steroids, vasopressin, growth hormone, insulin, and various vaccines. ${ }^{2}$ The mechanism behind the partial loss of adipose tissue is largely unknown. The injecting drug may induce macrophage activation and cytokine release. Cytokine activation inhibits lipogenesis and increases lipid catabolism. Hypo-perfusion of the local site due to variation in blood supply also contributes to the development of lipoatrophy. Hisamichi and colleagues reported two Japanese individuals who were on intramuscular corticosteroids and developed partial lipodystrophy later. Immunohistochemical examination showed a decrease in the size of individual lipocytes and scattered macrophages in affected adipose tissue and surrounding connective tissue.

Buttock and arm muscles are the common sites for intramuscular injections in older children and adults but they are less developed in toddlers and should be avoided for intramuscular injection. No specific treatment is available for this condition and it depends on the underlying aetiology. Parental and patient reassurance is the mainstay of the treatment and cosmetic procedures may be required in concerned individuals.

\section{Learning points}

Acquired localised lipodystrophy can occur with various inflammatory conditions, connective tissue disorders, HIV infection, metabolic syndromes, and intramuscular injections.

- Buttock and arm muscles are less developed in toddlers and should be avoided for intramuscular injection.

- Parental and patient reassurance is the mainstay of the treatment and cosmetic procedures may be required in concerned individuals. 
Contributors IKS: patient management, literature review, and initial draft manuscript preparation. JY: clinician-in-charge, critical review of manuscript for important intellectual content, and final approval of the version to be published. LD: patient management, literature review, and initial draft manuscript preparation.

Funding The authors have not declared a specific grant for this research from any funding agency in the public, commercial, or not-for-profit sectors.

Competing interests None declared.

Patient consent for publication Parental/guardian consent obtained.
Provenance and peer review Not commissioned; externally peer reviewed.

\section{REFERENCES}

1 Lightbourne M, Brown RJ. Genetics of Lipodystrophy. Endocrinol Metab Clin North Am 2017;46:539-54.

2 Sharawat IK, Dawman L. Localized Lipodystrophy following Single Dose Intramuscular Gentamycin Injection. Indian Dermatol Online J 2017;8:373-4.

3 Hisamichi K, Suga Y, Hashimoto Y, et al. Two Japanese cases of localized involutional lipoatrophy. Int J Dermatol 2002;41:176-7.

Copyright 2019 BMJ Publishing Group. All rights reserved. For permission to reuse any of this content visit

https://www.bmj.com/company/products-services/rights-and-licensing/permissions/

BMJ Case Report Fellows may re-use this article for personal use and teaching without any further permission.

Become a Fellow of BMJ Case Reports today and you can:

- Submit as many cases as you like

- Enjoy fast sympathetic peer review and rapid publication of accepted articles

- Access all the published articles

- Re-use any of the published material for personal use and teaching without further permission

\section{Customer Service}

If you have any further queries about your subscription, please contact our customer services team on +44 (0) 2071111105 or via email at support@bmj.com.

Visit casereports.bmj.com for more articles like this and to become a Fellow 